\title{
Analisis Penggunaan Variasi Register Berdasarkan Model Interaksi Speaking Dalam Media Sosial Youtube
}

\author{
Tutut Ayu Dwijayanti1 ${ }^{1)}$, Gigit Mujianto ${ }^{2)}$ \\ tututayu2015@gmail.com ${ }^{1)}$, gigit@umm.ac.id ${ }^{2)}$ \\ Pendidikan Bahasa Indonesia, Universitas Muhammadiyah Malang, \\ Jalan Raya Tlogomas 246 Malang, Indonesia ${ }^{12)}$
}

\begin{abstract}
Abstrak. Penelitian ini bertujuan untuk (1) Mendeskripsikan Variasi Bahasa Register, (2) Mendeskripsikan Aspek Model Fungsional SPEAKING, (3) Mendeskripsikan Media Sosial Beserta Pengaruhnnya. Penelitian ini menggunakan pendekatan sosiolinguistik, adapun jenis penelitian ini adalah kualitatif. Metode yang digunakan adalah deskriptif analisis. Sumber data dalam penelitian ini adalah Media Sosial Youtube. Data dalam penelitian ini berupa kutipan kata, frasa, klausa atau kalimat dalam video Youtube. Teknik pengumpulan data yang digunakan dalam penelitian ini adalah dokumentasi. Setelah data terkumpul dilakukan proses klasifikasi data kemudian dilakukan analisis. Proses analisis dilakukan secara bersamaan, seluruh korpus dikelompokkan menurut persamaan model fungsional dan variasi bahasa dalam media sosial Youtube. Dengan demikian, hasil penelitian diketahui variasi bahasa register berdasarkan (1) Setting atau tempat dan scene atau suasana, (2) Participants atau peserta tutur, (3) End atau tujuan tutur, (4) Act sequences atau pokok tuturan, (5) Key atau nada tutur, (6) Instrumental ities atau sarana tutur, (7) Norms atau norma tutur, dan (8) Genre atau jenis tuturan dalam media sosial Youtube.
\end{abstract}

Kata Kunci: sosiolinguistik, variasi register, model fungsional SPEAKING.

\section{Pendahuluan}

Individu merupakan bagian dari masyarakat yang terlibat dalam suatu aktifitas sosial, dalam melakukan suatu aktifitas suatu individu memerlukan suatu bahasa untuk berinteraksi serta berkomunikasi satu sama lain. Menurut R. Grosse dan A. Neubert (dalam Rokhman, 2013: 5), aspek sosiologi dan aspek sosiolinguistik merupakan aspek tinjauan dari hubungan timbal balik antara masyarakat dan bahasa. Dengan demikian bidang sosiologi termasuk aspek sosiologi bahasa dan bidang linguistik termasuk aspek sosiolinguistik.

Adapun faktor yang mempengaruhi variasi dan ragam bahasa adalah faktor linguistik dan nonlinguistik (Mustikawati, 2015). Oleh karena itu, Malabar (2015) mengartikan ragam bahasa ada dua. Pertama, ragam sosial penutur bahasa dan fungsi bahasa. Seragamnya bahasa dapat terjadi apabila kelompok etnis merupakan penutur bahasa. Kedua, beraneka ragamnya alat interaksi masyarakat bahasa sudah memenuhi fungsi di dalamnya. Dengan demikian, ragam bahasa dapat digolongkan berdasarkan keragaman sosial dan fungsi kegiatan masyarakat.

Halliday (dalam Malabar, 2015) membedakan variasi bahasa berdasarkan penutur dan pemakaian, penggunaan variasi bahasa berdasarkan penuturnya antara lain idiolek, dialek, kronolek, dan sosiolek, sedangkan variasi bahasa berdasarkan dengan penggunaanya, pemakaiannya atau fungsinya disebut register (Nababan, dalam Malabar, 2015). Variasi register memiliki ciri diantaranya variasi bahasa berdasarkan penggunaannya dan ditentukan berdasarkan apa yang sedang dikerjakan dan sifat kegiatan yang menggunakan bahasa, dan mencerminkan proses sosial yang merupakan berbagai kegiatan sosial (Chaer, dalam Prasetya, 2013). 
Tindakan atau interaksi, Peristiwa, dan situasi bahasa akan mempengaruhi satu sama lain. Jika salah satunya terjadi perbedaan maka akan terjadi perbedaan juga pada yang lain (Hymes, dalam Mahali, 2008). Hymes (1996) sendiri mengkategorikan peristiwa tutur ke dalam delapan komponen. Kedelapan komponen tersebut saling terhubung satu sama lain. Kedelapan komponen tersebut diakronimkan menjadi SPEAKING. Tindakan atau interaksi bahasa juga terjadi dalam media sosial (social networking) yang merupakan sebuah media online dimana para penggunanya bisa dengan mudah berpartisipasi, berbagi, dan menciptakan dalam waktu yang cepat serta tak terbatas (Wilga, 2016). Masyarakat menjadi hiperaktif di media sosial ini, sering mem-posting kegiatan sehari-harinya seakan-akan menggambarkan gaya hidup mereka yang mencoba mengikuti perkembangan jaman.

Penutur yang tidak homogen menyebabkan suatu bahasa menjadi beragam dan bervariasi, namun hal ini juga disebabkan oleh interaksi masyarakat yang beraneka ragam pula. Oleh karena itu, keragaman bahasa sangat diperlukan untuk keragaman suatu kegiatan. Keragaman akan bertambah jika penutur suatu bahasa berjumlah banyak dalam suatu wilayah yang luas. Ragam bahasa atau variasi yang fokusnya pada pengguna disebut dengan register. Register merupakan konsep semantik yang diartikan sebagai suatu makna dengan susunan sarana, peserta hingga situasi secara khusus serta dikaitkan satu sama lain. Menurut Halliday (dalam Prasetya, 2013) register memperlihatkan berbagai aspek yaitu dari tingkat sosial, proses sosial, hingga berbagai macam kegiatan sosial yang dapat melibatkan banyak individu. Dengan demikian dapat disimpulkan, bahwa register adalah ragam bahasa yang digunakan saat ini, tergantung pada apa yang sedang dikerjakan dan sifat kegiatannya.

Register juga dipengaruhi oleh beberapa faktor dalam kemunculannya, menurut Hudson (dalam Mustikawati, 2015) berpendapat bahwa "register as varieties according to user", maksudnya ialah register bergantung pada penggunanya, apabila penggunanya berbeda maka akan berbeda pula bahasa yang digunakan. Hal ini sependapat dengan Spolsky (dalam Mustikawati, 2015) berpendapat bahwa "register is variety associated with a specific function", maksudnya register kan memiliki fungsi yang beraneka ragam atau berbeda-beda, seperti hubungan pembicara dengan lawan bicara, topik pembicaraannya, dan sebagainya karena bergantung pada fungsi. Adapun perubahan register dipengaruhi oleh faktor-faktor yakni topik pembicaraan, seperti asmara, politk, pendidikan, hukum dan sebagainya. Peserta tutur, seperti teman, guru, kekasih, orang tua, dan sebagainya. Tujuan berbicara, seperti meminta tolong, menceritakan suatu permasalahan, dan sebagainya. Perasaan pada saat berkomunikasi, seperti senang, sedih, marah, terpaksa, malu, dan sebagainya. jenis komunikasi yang akan digunakan, misalnya lisan atau tulis.

Menurut Malabar (2015) variasi register ini digunakan dalam bidang sebagai berikut.

a. Militer. Bahasa militer terkenal tegas dan ringkas, hal tersebut sesuai dengan pola hidupnya yang penuh intruksi dan sangat disiplin. Keringkasan suatu bahasa dan sifatnya tegas serta berbagai bentuk akronim tidak menjadi persoalan bagi kalangan militer, namun bagi orang awam akan sukar untuk dipahami.

b. Jurnalistik. Ciri dari pemakaian bahasa jurnalistik adalah sifatnya yang sederhana, ringkas, deskriptif dan komunikatif. Hal ini bertujuan agar pembaca akan mudah memahami jika yang dideskripsikan sederhana, ringkas serta jelas. 
c. Ilmiah. Ragam bahasa ilmiah biasanya bersifat bebas, jelas, lugas serta tidak bermetafora. Hal ini dikarenakan kepastian akan makna serta tafsiran. Oleh karena itu, bahasa ilmiah tidak bermetafora serta tidak beridiom.

Menurut Martin Joos (dalam Malabar, 2015) bentuk register berdasarkan tingkat keformalan dibagi menjadi lima, sebagai berikut.

a. Beku (Oratorical atau frozen). Bentuk ini merupakan bentuk yang paling formal biasanya digunakan pada saat upacara yang resmi atau acara yang khidmat. Jadi kaidah dan pola yang sudah ditetapkan dan tidak boleh diubah menjadikan bentuk ini adalah bentuk yang paling formasl. Misalnya yang terdapat pada undang-undang, akte, sertifikat, dokumen dan sebagainya.

b. Formal (Deliberative). Bentuk ini merupakan bentuk yang sering dipakai dalam berpidato, ceramah, dan kalimat yang ada dibuku-buku. Kaidah dan polanya tertata secara standart, misalnya pembicaraan dengan seorang dosen, diskusi pada saat kuliah, atau acara pernikahan biasanya menggunakan bentuk bahasa ini.

c. Usaha (Consultative). Bentuk ini biasanya digunakan di sekolah, misalnya konsultasi, rapat dan sebagainya. Jadi bentuk ini merupakan bahasa operasional, karena bentuknya berada di tengah-tengah antara nonformal dan formal.

d. Santai (Casual). Bentuk ini biasanya digunakan pada acara atau kegiatan tidak resmi, misalnya berkomunikasi dengan teman atau keluarga. Bentuk ini banyak menggunakan alergo yaitu suatu ujaran atau kata yang diringkas atau diperpendek. Susunan kalimatnya dapat berupa bahasa daerah atau unsur leksikal dialek.

e. Intim (Intimate). Bentuk ini digunakan oleh pemakainya yang sudah saling akrab, misalnya dengan sahabat, kekasih, bahkan anggota inti keluarga. Hal ini ditandai dengan bahasa yang pendek, tidak lengkap, hingga pelafalan yang tidak jelas, karena peserta tuturnya sudah mengerti dan berpengetahuan sama.

Hymes (1996) menganggap bahwa bahasa merupakan salah satu ciri dimensi sosial budaya, dan merupakan salah satu dari sejumlah fungsi sosial yang ada dalam masyarakat tutur tersebut. Setiap tuturan dipengaruhi oleh sejumlah komponen tutur yang saling berkaitan, dan bentuk tutur dihasilkan oleh penutur akan diwarnai oleh unsur-unsur komponen. Hymes (dalam Ibrahim, 2009) mengakronimkan dengan kata SPEAKING pada komponen tutur, yakni S (setting dan scene), setting merupakan tempat serta suasana percakapan berlangsung, sedangkan scene merupakan suasana atau situasi pada peristiwa yang sedang berlangsung. $\mathrm{P}$ atau participant, merupakan pelaku yang sedang melakukan suatu percakapan, diantaranya terdapat penutur, mitra tutur, dan orang yang dituturkan. E atau end, adalah maksud atau tujuan pembicaraan yang dituturkan oleh penutur yang ingin disampaikan terhadap mitra tutur. A atau $a c t$, adalah pokok tuturan atau topik pembicaraan yang berlangsungnya suatu percakapan atau peristiwa percakapan atau merupakan ujaran yang diujarkan oleh penutur mengandung maksud yang menggunakan bahasanya sendiri yang khas. $\mathrm{K}$ atau key, merupakan nada tutur atau tinggi rendahnya suatu bunyi yang diujarkan oleh peserta tutur. I atau instrument, adalah penutur menggunakan bahasa sebagai

alat berkomunikasi dengan mitra tutur, dalam menggunakan bahasa peserta tutur menggunakan saluran tutur berupa lisan dan saluran tutur berupa tulisan. $\mathrm{N}$ atau norms of interaction, merupakan norma atau aturan dalam berbicara yang diterapkan oleh penutur dan 
mitra tutur, misalnya sopan santun dalam bertutur dengan mitra tutur. $\mathrm{G}$ atau genre, merupakan jenis tuturan, terdapat dua jenis tuturan yaitu jenis bentuk penyampaian kalimat tidak langsung dan jenis bentuk penyampaian kalimat langsung.

Dewasa ini masyarakat tidak ada batasan untuk berkomunikasi, karena adanya suatu media sosial yang dapat mendekatan yang jauh. Kaplan dan Michael Haenlein (dalam Wilga, 2016) berpendapat bahwa media sosial adalah sebulah kelompok aplikasi yang menggunakan jaringan internet, adanya media sosial ini karena hasil dari teknologi dan ideologi. Bentuk media sosial kini sangat beragam seperti blog sosial, majalah digital, dan masih banyak lagi. Masingmasing bentuk media sosial tersebut memiliki kekurangan dan kelebihan tersendiri. Adapun klasifikasi media sosial berdasarkan fungsinya, antara lain yakni sebagai berikut.

a. Proyek Kolaborasi. Website mengijinkan usernya untuk dapat mengubah, menambah, ataupun me-remove konten - konten yang ada di website ini. contohnya wikipedia.

b. Virtual social world. Dunia virtual yang dimana penggunanya merasa hidup di dunia virtual, sama seperti virtual game world, berinteraksi dengan yang lain. Namun, Virtual Social World lebih bebas, dan lebih ke arah kehidupan, contohnya second life.

c. Blog dan microblog. User lebih bebas dalam mengekspresikan sesuatu di blog ini seperti curhat ataupun mengkritik kebijakan pemerintah. contohnya twitter.

d. Konten. Para user dari pengguna website ini saling meng-share konten - konten media, baik seperti video, ebook, gambar, dan lain - lain. contohnya youtube.

e. Virtual game world. Dunia virtual, dimana mengreplikasikan lingkungan 3D, dimana user bisa muncul dalam bentuk avatar - avatar yang diinginkan serta berinteraksi dengan orang lain selayaknya di dunia nyata. contohnya game online.

f. Situs jejaring sosial. Aplikasi yang mengizinkan user untuk dapat terhubung dengan cara membuat informasi pribadi sehingga dapat terhubung dengan orang lain. Informasi pribadi itu bisa seperti foto - foto, contoh facebook.

Jenis-jenis media sosial tersebut tentunya memiliki dampak yang dapat mempengaruhi perubahan kehidupan sosial dalam masyarakat (Cahyono, 2016:). Perbahan-perubahan tersebut dapat berupa perubahan hubungan sosial yang di dalamnya terdapat nilai-nilai, sikap dan pola perilaku diantara kelompokkelompok dalam masyarakat. Perubahan sosial positif seperti kemudahan memperoleh dan menyampaikan informasi, memperoleh keuntungan secara sosial dan ekonomi. Dampak positif dari media sosial adalah memudahkan kita untuk berinteraksi dengan banyak orang, memperluas pergaulan, jarak dan waktu bukan lagi masalah, lebih mudah dalam mengekspresikan diri, penyebaran informasi dapat berlangsung secara cepat, biaya lebih murah. Sedangkan perubahan sosial yang cenderung negatif seperti munculnya kelompok kelompok sosial yang mengatasnamakan agama, suku dan pola perilaku tertentu yang terkadang menyimpang dari norma - norma yang ada. Sedangkan dampak negatif dari media sosial adalah menjauhkan orang-orang yang sudah dekat dan sebaliknya, interaksi secara tatap muka cenderung menurun, membuat orang-orang menjadi kecanduan terhadap internet, menimbulkan konflik, masalah privasi, rentan terhadap pengaruh buruk orang lain.

Penelitian ini difokuskan pada (1) Setting atau tempat dan scene atau suasana, (2) Participants atau peserta tutur, (3) End atau tujuan tutur, (4) Act sequences atau pokok tuturan, (5) Key atau nada tutur, (6) Instrumental ities atau sarana tutur, (7) Norms atau norma tutur, dan (8) Genre atau jenis tuturan dalam media sosial Youtube berdasarkan variasi bahasa register. Dengan 
demikian, dapat diketahui tempat atau suasana, peserta tutur, tujuan tutur, pokok tuturan, nada tutur yang dipakai, sarana tutur yang dipakai, norma tutur yang diterapkan, dan jenis tuturan dalam media sosial Youtube berdasarkan variasi bahasa register.

\section{Metode}

Penelitian ini bersifat deskriptif yaitu peneliti menganalisis data dengan cara menggambarkan suatu data yang telah terkumpul (Sugiyono, 2018). Adapun jenis penelitian ini adalah kualitatif, penelitian kualitatif merupakan jenis pengumpulan data pada suatu latar alamiah dengan maksud menafsirkan fenomena yang terjadi (Anggito \& Setiawan, 2018). Sumber data dalam penelitian ini adalah Media Sosial Youtube. Data dalam penelitian ini berupa kutipan kata, frasa, klausa atau kalimat dalam video Youtube. Teknik pengumpulan data yang digunakan dalam penelitian ini adalah dokumentasi. Setelah data terkumpul dilakukan proses klasifikasi data kemudian dilakukan analisis. Proses analisis dilakukan secara bersamaan, seluruh korpus dikelompokkan menurut persamaan model fungsional dan variasi bahasa dalam media sosial Youtube.

\section{Hasil dan Pembahasan}

\section{Variasi Register Berdasarkan Aspek Model Fungsional Setting atau Scene dalam Media Sosial Youtube}

Pada media sosial Youtube terdapat Setting dan Scene. Kedua bentuk tersebut antara lain sebagai berikut.

\section{Setting atau tempat}

Setting atau tempat merupakan petunjuk keberadaan seseorang melangsungkan suatu percakapan atau suatu kegiatan. Ketika seseorang melangsungkan suatu percakapan atau kegiatan pasti mempertimbangkan dan memilih tempat yang cocok akan percakapan dan kegiatan tersebut, sehingga dapat berlangsung dengan aman serta nyaman. Hal ini dapat dilihat pada kutipan data berikut.

\section{"Di Gedung BNPB Jakarta". (Video. 1)}

Data yang terperoleh, diketahui berada di gedung BNPB Jakarta. BNPB adalah Badan Nasional Penanggulangan Bencana yang sekarang sebagai gugus tugas percepatan penanganan Covid-19. Informasikan mengenai virus corona mulai dari cara pencegahan, gejala penyakit, rumah sakit rujukan, hingga kasus yang positif corona di Indonesia dapat diketahui di gedung BNPB, karena pihak BNPB menginformasikan pertama kali di gedung tersebut.

Selain di tempat-tempat resmi tersebut, adapun tempat-tempat yang melangsungkan percakapan dan kegiatan di tempat non-resmi. Hal ini dapat dilihat pada kutipan data berikut.

“Studio Podcast Deddy Coebuzier, Jakarta". (Video. 2)

Data tersebut bertempat di studio Podcast milik pribadi Deddy Coebuzier. Studio Podcast yaitu tempat yang digunakan untuk merekam audio visual yang dapat didengarkan serta ditonton, dan juga dilengkapi berbagai alat penunjang agar terlaksananya rekaman 
tersebut, seperti mikrofon, kamera, komputer, digital audio workstation, dan sebagainya.

Tidak semua kegiatan resmi berada di tempat yang resmi juga, dan tidak semua suatu percakapan dan suatu kegiatan yang non-resmi berada di tempat yang non-resmi juga. Hal ini dapat dilihat pada kutipan data berikut.

"Pantai Grajakan, Jatim merupakan tempat latihan Kopaska". (Video.3)

Data di atas menunjukkan pantai Grajakan merupakan salah satu tempat pelatihan bagi kopaska. Pantai Grajakan berada di Jawa Timur, tepatnya di Banyuwangi. Karakteristik dari pantai ini adalah garis pantainya yang panjang, sehingga anggota kopaska dapat latihan dengan leluasa.

Pelatihan Kopaska tidak hanya di tepi pantai saja, melainkan di tengah hingga di dalam laut. Hal ini dapat dilihat pada kutipan data berikut.

“Tengah laut". (Video.3, menit ke 15:03)

Data di atas, tengah laut merupakan tempat khusus anggota kopaska berlatih menyelam dengan berbagai cara seperti lompat langsung dari kapal cepat disertai alat-alat yang mendukung, para anggota dilatih untuk menyusup ke tempat musuh secara senyap lewat dasar laut.

\section{Snene atau Suasana}

Snene atau suasana atau disebut juga dengan situasi merupakan suatu keadaan dalam peristiwa yang menyangkut perihal waktu berlangsungnya suatu peristiwa. Tidak hanya waktu saja, namun meliputi kenyamanan dan keamanan suatu tempat berlangsungnya peristiwa. Hal ini dapat dilihat pada kutipan data berikut.

“Situasi sedang dilaksanakan konferensi pers." (Video.1)

Pada data tersebut, suasana sedang dilaksanakan konferensi pers. Konferensi pers merupakan acara khusus yang dibuat guna sebagai sarana untuk mengumumkan atau menjelaskan suatu kebijaksanaan dengan maksud untuk menguatkan pengertian dan penerimaan pada masyarakat, tentu saja suasana ramai dengan wartawan-wartawan.

Berbagai suasana dan situasi dapat terjadi pada berlangsungnya suatu peristiwa. Tidak selalu ramai, bising, dan sebagainya. Hal ini dapat dilihat pada kutipan data berikut.

"Situasi diskusi berlangsung dengan aman, nyaman, dan efektif." (Video.2)

Data tersebut menggabarkan situasi selama podcast berlangsung secara aman, artinya tidak ada gangguan yang mengancam, kemudian berlangsung secara nyaman karena tidak ada ancaman atau paksaan dari pihak manapun, dan efektif karena yang dibahas dalam podcast tersebut sesuai dengan permasalahan yang sedang terjadi, sehingga point yang disampaikan dipikir penting serta dapat diimplementasikan dalam keseharian.

Pada suatu video yang ada di media sosial suasana yang sepi belum tentu aman dan nyaman. Hal ini dapat dilihat pada kutipan data berikut. 
"Menjelang matahari terbenam." (Video.3, menit ke 18:15)

Data tersebut merupakan suasana bagi anggota siswa kopaska dalam berlatih kekopaskaan. Latihan disengaja pada menjelang matahari terbenam karena, untuk melatih kepribadian serta kemampuan dalam Angkatan Laut yang identik dengan air, sehingga para siswa harus menguasai di dalam air, permukaan, dan sabotase.

Pada video 3 tidak hanya satu suasana. Adapun suasana lain sebagai berikut.

“Tersamar gelapnya malam dan deburan ombak". (Video.3, menit ke 19:14)

Data di atas merupakan gambaran suasana anggota kopaska sedang berlatih, harus dengan cermat meski pengelihatan tersamarkan oleh gelapnya malam, dan tetap kuat menerjang ombak yang melintang. Betapa kerasnya latihan yang dilaksanakan demi mencetak kopaska yang tangguh.

\section{Variasi Register Berdasarkan Aspek Model Fungsional Participants atau peserta tutur dalam Media Sosial Youtube}

Pada media sosial Youtube setiap video terdapat peserta tutur atau pelaku dalam sebuah percakapan. Peserta tutur tersebut terdapat tiga diantaranya sebagai berikut.

\section{Penutur}

Penutur merupakan pelaku dalam sebuah percakapan. Penutur juga merupakan seseorang yang memberikan suatu informasi. Hal ini dapat dilihat pada kutipan data berikut.

“Achmad Yurianto." (Video.1)

Pada data di atas, penutur merupakan orang yang menyampaikan suatu informasi dan orang yang menyampaikan informasi pada data tersebut adalah Achmad Yurianto dalam terselenggaranya konferensi pers pada 1 April 2020. Beliau menyampaikan tentang pandemi Covid-19 di Indonesia, menyampaikan jumlah pasien yang positif, pasien yang sembuh, hingga pasien yang meninggal dunia.

Penutur juga dapat berupa pemandu suatu acara seperti talk show. Hal ini dapat dilihat pada kutipan data berikut.

\section{“Deddy Coebuzier.” (Video.2)}

Data yang diperoleh dalam video tersebut, Deddy Coebuzier merupakan pemilik studio podcast beserta host diacara podcast tersebut, sebagai seorang pembawa acara atau host keramah tamahan dan komunikatif sangat diterapkan oleh Deddy Coebuzier. Dengan demikian, lawan tutur akan merasa senang dan menjawab pertanyaan dengan tenang.

Penutur juga dapat berupa pimpinan dalam suatu organisasi. Misalnya komando yang memberikan arahan terhadap anggotannya. Hal ini dapat dilihat pada kutipan data berikut. 
"Mayor Yudo Ponco." (Video.3)

Pada data tersebut Mayor Yudo Ponco adalah selalu Komandan Sekolah Kopaska. Beliau menjelaskan tata pelaksanaan latihan combine dari berbagai materi sebelumnya dan dirangkai dalam satu misi yang harus dilaksanakan oleh anggota siswa Kopaska.

\section{Mitra Tutur}

Mitra tutur merupakan bagian dari pelaku dalam sebuah percakapan. Keberadaan mitra tutur dapat membantu penutur melangsungkan percakapan dengan baik. Hal ini dapat dilihat pada kutipan data berikut.

\section{"Wartawan". (Video.1)}

Data di atas, mitra tutur merupakan orang yang menerima suatu informasi yang diberikan oleh penutur, sekaligus dapat menanggapi percakapan yang sedang berlangsung. Pada data tersebut wartawan sebagai penerima suatu informasi tersebut dan akan segera disampaikan kepada masyarakat. Dengan demikian, masyarakat dapat mengetahui berita terkini.

Mitra tutur juga dapat menanggapi pernyataan penutur. Hal ini dapat dilihat pada kutipan data berikut.

\section{“dr. Tirta.” (Video.2)}

Pada data di atas, dr. Tirta adalah mitra tutur Deddy Coebuzier. Pembicaraan dalam podcast tersebut isinya berupa diskusi, sehingga dr. Tirta sebagai lawan tutur Deddy Coebuzier tidak hanya mendapat informasi saja, tetapi dapat juga memberikan suatu informasi yang bermanfaat bagi masyarakat luas seputar kesehatan.

\section{Orang yang Dituturkan}

Orang yang dituturkan merupakan orang yang dibicarakan atau dibahas oleh penutur dan mitra tutur dalam suatu percakapan. Hal ini dapat dilihat pada kutipan data berikut.

“Todak, merupakan salah satu siswa pelatihan Kopaska." (Video.3)

Pada data di atas, Todak adalah salah satu siswa Sekolah Kopaska dan merupakan orang yang dibicarakan oleh penutur dan mitra tutur. Menurut penutur, Todak dan siswa yang lain dirasa cukup mampu dalam menjalankan misi setelah mendapatkan materi dan pelatihan selama sekolah Kopaska.

\section{Variasi Register Berdasarkan Aspek Model Fungsional End atau tujuan tutur dalam Media Sosial Youtube}

Pada media sosial Youtube setiap video memiliki tujuan dan maksud yang ingin disampaikan lewat dalam suatu video. Hal tersebut sebagai berikut. 
"Konfirmasi." (Video.1, menit ke 0:38)

Pada data di atas adalah konfirmasi. Konfirmasi merupakan penegasan atau pembenaran suatu informasi. Penegasan atau pembenaran suatu informasi sangat perlu dilakukan agar tidak terjadi informasi yang simpang siur dan membuat masyarakat semakin panik dengan adaya infornasi-informasi hoaks terkait Covid-19. Penegasan tersebut diberikan oleh Achmad Yurianto, selaku juru bicara pemerintah untuk penanganan kasus Corona.

Data selanjutnya masih terkait dengan dunia kesehatan atau medis. Hal ini dapat dilihat sebagai berikut.

"ICU." (Video.2, menit ke 4:38)

Data selanjutnya adalah Intensive Care Unit atau ICU adalah perawatan di rumah sakit yang dikhususkan untuk pasien dewasa dengan kondisi yang mengancam jiwa. Oleh sebab itu, pasien yang mengalami kondisi kritis atau mengacam jiwa biasanya akan dipantau secara intensif dengan peralatan khusus oleh tenaga medis yang sudah terampil dan terlatih. Para tenaga medis yang kebagian tugas jaga di ruang ICU harus siap jika sewaktu-sewaktu ada pasien yang membutuhkan pertolongannya.

Tenaga medis yang terlatih dan terampil tidak hanya bertugas untuk mengobati pasien yang sakit, akan tetapi juga sebagai agen pencegahan. Hal ini dapat dilihat pada kutipan data berikut.

“Agen prevensi.” (Video.2, menit ke 12:11)

Agen prevensi adalah agen pencegahan yang merupakan salah satu tugas tenaga medis selain bertugas mengobati dan merawat pasien. Hal ini, sebagai agen pencegahan yaitu mencegah dalam bidang kesehatan ini dipikir cukup mumpuni dari pada mengobati. Mengetahui korban Covid-19 cukup banyak, oleh karena itu tenaga medis menghimbau masyaakat agar selalu menjaga kebersihan, menjaga kebugaran tubuh dan sebagainya.

Semua lapisan masyarakat indonesia bersatu untuk memerangi Covid-19. Tidak terkecuali pasukan-pasukan elit di Indonesia yang tetap berlatih untuk menjaga kesatuan Indonesia. Hal ini dapat dilihat pada kutipan data berikut.

\section{"Pasukan elit Indonesia." (Video.3)}

Data di atas memperlihatkan bahwa Indonesia memiliki Pasukan elit, yaitu satuan tentara yang dipilih dan disatukan menjadi satuan yang sama. Pasukan elit dibuat agar bisa mengerjakan tugas pasukan reguler secara lebih baik. Semua pasukan khusus adalah pasukan elit, tetapi pasukan elit belum tentu pasukan khusus. Istilah ini sebenarnya agak samar-samar, karena kriteria pasukan khusus bisa berbeda pada setiap negara, tetapi pasukan khusus tidak sama dengan pasukan elit. Pasukan khusus biasanya terdiri dari kelompok kecil yang sangat terlatih, yang dipersenjatai dengan senjata khusus, yang bekerja secara mandiri, siluman, 
dengan kecepatan tinggi, dan dengan kerja sama yang dekat.

\section{Variasi Register Berdasarkan Aspek Model Fungsional Act sequences atau pokok tuturan dalam Media Sosial Youtube}

Pada media sosial Youtube, suatu video terdapat pokok tuturan. Pokok tuturan tersebut sebagai berikut.

\section{"Lawan Corona.” (Video.2)}

Kutipan data di atas, virus corona yang awal mulanya di Wuhan, China ini tidak bisa dibiarkan begitu saja. Banyak korban yang meninggal dunia, sehingga perlu adanya

perlawanan agar tidak menyebar. Pemerintah Indonesia mengusahakan berbagai cara agar penyebaran covid-19 tidak semakin luas, kebijakan-kebijakan baru telah dilaksanakan namun tetap mempertimbangkan dengan matang. Tidak hanya pemerintah saja yang turun tangan tangan melainkan semua lapisan masyarakat mulai dari golongan bawah hingga atas.

Semua bersatu bahu-membahu untuk memerangi Covid-19. Tidak ketinggalan juga pasukan elit Indonesia yang senantiasa menjaga keamanan Indonesia. Indonesia memiliki berbagai pasukan elit. Salah satu pasukan elit tersebut adalah Kopaska. Hal ini dapat dilihat pada kutipan data sebagai berikut.

“Kopaska.” (Video.3, menit ke 0:45)

Kutipan data di atas merupakan kepanjangan dari Komando Pasukan Katak. Tugas utama Kopaska adalah operasi pendaratan kekuatan amfibi, menyerbu kapal dan pangkalan musuh, serta penyiapan perebutan pantai, menghancurkan instalasi bawah air. Akan tetapi, apabila sedang tidak mendapat tugas-tugas tersebut, maka para Kopaska ditugaskan menjadi pengawal Presiden Indonesia.

Kopaska bertugas menanggulangi beberbagai aksi kejahatan. Hal ini dapat dilihat pada kutipan berikut.

\section{"MIO atau Maritime Interdiktion Operation." (Video.3, menit ke 1:39)}

Kutipan data MIO tersebut merupakan adalah penanggulangan aksi kejahatan dan terorisme di laut. MIO atau disebut dengan Maritime Interdiktion Operation Tujuan dari MIO yaitu untuk mengganggu, memperlambat dan merusak kekuatan musuh atau persediaan perjalanan ke daerah pertempuran. Butuh kerja cepat dalam hal ini, agar misi yang dijalankan berhasil. Selain MIO, Kopaska juga berlatih VBSS. VBSS merupakan singkatan dari visit, board, search, and seizure. Tim VBSS dirancang untuk menangkap kapal musuh, memerangi terorisme, pembajakan dan penyelundupan. Hal ini diberikan pada semua anggota siswa Kopaska dalam rangka penegakan hukum di laut. 
Variasi Register Berdasarkan Aspek Model Fungsional Key atau nada tutur dalam Media Sosial Youtube

Pada media sosial Youtube, nada tutur berupa tinggi rendahnya suatu bunyi yang dituturkan. Hal tersebut sebagai berikut.

"Ada yang bilang, Corona bagus pake antibiotik. Gak, gue klarifikasi, antibiotik itu buat bakteri”. (Video.2, menit ke 15:13)

Kutipan kalimat di atas, antibiotik adalah kelompok obat yang digunakan untuk mengatasi dan mencegah infeksi bakteri. Obat ini bekerja dengan cara membunuh dan menghentikan bakteri berkembang biak di dalam tubuh. Oleh karena itu, dr. Tirta tidak menyarankan seseorang yang mencegah Corona untuk mengkonsumsi antiotik, Corona adalah sebuah virus bukan bakteri. Antibiotik diucapkan dengan nada rendah, karena menandakan keseriusan serta kedalaman suatu bahasan yang sedang dibahas.

Suatu percakapan tentu saja menggunakan berbagai nada dalam menuturkan sebuah kalimat. Hal ini dapat dilihat sebagai berikut.

“Ada SOP sebenernya di dokter" (Video.2, menit ke 16:32)

Kutipan data di atas bahwa SOP singkatan dari Standart Operasional Prosedur, setiap dokter di rumah sakit pasti ada SOP. SOP diucapkan dengan nada tinggi atau dengan lantang karena karena bermaksud untuk memberitahukan dan membenarkan adanya hal tersebut, bahwa benar adanya SOP pada dokter di setiap rumah sakit. Jadi setiap dokter atau perawat tidak dapat melakukan hal yang tidak perlu, karena harus mentaati SOP yang berlaku.

Penggunaan nada tinggi sering kali digunakan oleh TNI, POLRI, dan sebagainya. Nada tinggi akan terdengar tegas dan terlihat bersemangat. Hal ini dapat dilihat pada kutipan data sebaga berikut.

\section{“Angkat tangan, merapat kedinding, buka kaki” (Video.3, 7:30)}

Pada kutipan data di atas memberitahukan bahwa terdapat penyergapan dan para anggota Kopaska sedang membekuk pelaku. Para Kopaska melaksanakan dengan baik. Tidak ada rasa takut sehingga nada yang digunakan ketika berhasil menyergap dan menangkap penjahat adalah dengan nada tinggi, tegas serta cekatan dalam bertindak. Para Kopaska membekuk pelaku dan mengamankan agar tidak kabur.

\section{Variasi Register Berdasarkan Aspek Model Fungsional Instrumental ities atau sarana tutur Media Sosial Youtube}

Pada media sosial Youtube, sarasa tutur kebanyakan menggunakan lisan. Oleh karena itu, penonton video cukup menyimak dan mendengarkan, tidak perlu membaca. Hal ini dapat dilihat sebagai berikut.

"Pada kasus-kasus yang kita rawat diseluruh tanah air, untuk kasus terkonfirmasi 
Data di atas awalnya berupa data tulis yang kemudian disampaikan kembali oleh Bapak Achmad Yurianto melalui lisan dalam terselenggaranya konferensi pers pada 1 April 2020. Beliau selaku juru bicara pemerintah untuk penanganan kasus Corona. Menyampaikan dan mengkonfirmasi jumlah terkini, untuk mengindari berita hoaks di lingkungan masyarakat luas. Beliau mengatakan kasus tersebut pada tanggal 1 April 2020 rumah sakit di seluruh Indonesia pasien yang positif Covid-19 berjumlah 1.677 orang. Hal tersebut mengalami pertambahan sebesar 149 orang di seluruh Indonesia.

Pada media sosial Youtube bentuk yang diunggah berupa video, sehingga kebanyakan berupa audio visual. Hal ini dapat dilihat pada data berikut.

Dr. Tirta: "Kalau orang kena virus, imun itu udah ngerti, imun tubuh tu udah pinter, imun tubuh itu adakah ciptaan Tuhan Allah yang bener-bener bangus banget, jadi klo virus masuk mereka udah kaya defend, responya kaya membela diri."

Deddy : "jadi fight back bassicnya" (video.2, menit ke 16:22)

Data tersebut terlihat adanya suatu percakapan antara Deddy dan dr. Tirta. Keduanya membahas tentang pandemi Covid-19, yang berada di Studio Potcast milik Deddy. Hal tersebut direkam dan diunggah sehingga dapat ditonton oleh masyarakat luas di media sosial Youtube. Mereka membahas bahwasanya yang dapat menangkal dan mengusir virus Corona adalah imun tubuh manusia, dalam percakapan tersebut dijelaskan bahwa imun tubuh akan menyerang virus dari luar tubuh yang berusaha masuk ke dalam tubuh manusia.

\section{Variasi Register Berdasarkan Aspek Model Fungsional Norms atau norma tutur Media Sosial Youtube}

Pada media sosial Youtube, suatu video yang bagus merupakan video yang terdapat norma di dalamnya sebagai berikut.

Deddy: "Dari dulu sebenernya kita mau ngundang ya, dari beberapa bulan yang lalu. Mau ngebahas tentang dokter slengekan, ngegas..."

Dr. Tirta: "Ha...ha...ha... langsung di kepo"

Deddy: "Dokter kok koyo ngene gimana to hehehe, begitu mau ngundang waaaa virus corona dateng"

Dr. Tirta: "Virus Corona dateng hahaha, gak bisa Mas, ntar diselipin ae lah". (Video.3, menit ke 0:40)

Kutipan data yang berupa kalimat di atas, memperlihatkan bentuk kesopanan dengan memanggil lawan bicara dengan sebutan "Mas". Kata "Mas" ini biasanya digunakan untuk mengormati orang yang meiliki usia lebih tua. Kata Mas dipakai oleh orang jawa, Mas sama halnya dengan kakak laki-laki. Dr. Tirta terlihat sangat menghormati Deddy selaku tuan rumah dan jika dilihat dari segi umur Deddy memiliki usia lebih tua dari dr. Tirta. 
Variasi Register Berdasarkan Aspek Model Fungsional Genre atau jenis tuturan Media Sosial Youtube

Pada media sosial Youtube terdapat dua jenis tuturan. Kedua jenis tersebut sebagai berikut.

\section{Jenis Bentuk Penyampaian Kalimat Langsung}

Kalimat langsung adalah kalimat yang diujarkan secara langsung. Biasanya merupakan pendapat pribadi ketika terjadi suatu percakapan. Hal ini dapat dilihat pada kutipan data sebagai berikut.

Dr. Tirta: "Ini trauma yang paling parah sebenernya di IGD, kalau dari tementemen dokter adalah trauma psikis. Jadi banyak orang yang dateng ke rumah sakit bahwa corona, wah itu buanyak Pak". (Video.2, menit ke 27:50)

Kutipan kalimat di atas merupakan kalimat langsung yang diujarkan oleh dr. Tirta. Dr. Tirta mengatakan bahwa rumah sakit ramai pengunjung karena banyak pasien yang sakit dan merasa bahwa dirinya positif Covid-19, sehingga berbondong-bondong untuk perisa, tes atau berobat ke rumas sakit. Hal tersebut merupakan trauma psikis yang disebabkan oleh pandemi Covid-19. Masyarakat tentu merasa cemas bahwa dirinya jika tertular, virus

ini dapat menyebabkan kematian dengan penyakit bawaan seperti hipertensi, jantung, dan sebagainya.

\section{Jenis Bentuk Penyampaian Kalimat Tidak Langsung}

Kalimat tidak langsung adalah kalimat yang diucapkan kembali oleh penutur, biasanya meniru kalimat yang telah diucapkan oleh orang lain. Hal ini bisa dilihat pada kutipan kalimat sebagai berikut.

Dr. Tirta: "Harapan gue adalah gue gak butuh muluk-muluk, "lah Tir ntar lo rugi". Ya harapan kalau gua, gua terjun di situ harapannya orang-orang lain yang punya rejeki lebih ..."

Deddy: "Ikutan!"

Dr. Tirta: “Akan ikutan”. (Video.2, menit ke 26:50)

Pada kutipan kalimat "Lah ntar lo rugi" merupakan kalimat tidak langsung, karena kalimat tersebut telah diucapkan oleh orang lain dan disampaikan ulang oleh dr. Tirta ketika mengobrol dengan Deddy. Maksud dari kalmat tersebut bertujuan memberitahu dr. Tirta kalau kemungkinan ketika dr. Tirta mendonasikan uang pribadinya untuk kepentingan melawan Covid-19 dirasa dapat merugikan dr. Tirta, namun dr. Tirta membantah hal tersebut. Keyakinan dr. Tirta dengan mengawali dengan diri sendiri akan dijadikan contoh oleh orang lain dan berharap apa yang dilakukannya dapat menginspirasi serta semakin banyak orang-orang yang mampu untuk berdonasi melawan Covid-19. 
Berangkat dari hasil penelitian dan pembahasan di atas, dapat disimpulkan bahwa variasi register berdasarkan kompenan SPEAKING, antara lain yakni setting dan scene. Participant, yaitu penutur, mitra tutur, dan orang yang dituturkan. End yakni maksud atau tujuan pembicaraan yang dituturkan oleh penutur yang ingin disampaikan terhadap mitra tutur. Act yaitu pokok tuturan atau topik pembicaraan. Key merupakan nada tutur atau tinggi rendahnya suatu bunyi yang diujarkan oleh peserta tutur. Instrument yaitu penutur menggunakan bahasa sebagai alat berkomunikasi dengan mitra tutur, dalam menggunakan bahasa peserta tutur menggunakan saluran tutur berupa lisan dan saluran tutur berupa tulisan. Norms of interaction merupakan norma atau aturan dalam berbicara yang diterapkan oleh penutur. Genre adalah jenis tuturan, terdapat dua jenis tuturan yaitu jenis bentuk penyampaian kalimat tidak langsung dan jenis bentuk penyampaian kalimat langsung.

\section{Daftar Pustaka}

Anggito, A., \& Setiawan, J. (2018). Metodologi Penelitian Kualitatif. Sukabumi: CV Jejak.

Cahyono, Anang Sugeng. 2016. Pengaruh Media Sosial Terhadap Perubahan Sosial Masyarakat di Indonesia. PUBLICIANA. 9(1).

Hymes, Dell. 1996. Ethnography, Linguistics, Narrative Inequality Toward an Undestanding of Voice. London: Taylor and Francis Publisher. (Online), https://books.google.co.id/books?id=tQF6AgAAQBAJ\&printsec=frontcover\&dq=Ethn ography,+Linguistics,+Narrative+Inequality+Toward+an+Understanding+of+Voice\&hl =id\&sa=X\&ved=0ahUKEwi6yZ6cqJboAhUVheYKHUx5A98Q6AEILDAA\#v=onepag e\&q=Ethnography\%2C\%20Linguistics\%2C\%20Narrative\%20Inequality\%20Toward\% 20an\%20Understanding\%20of\%20Voice\&f=false, diakses pada 14 Februari 2020.

Ibrahim, Abdul Syukur. 2009. Kesemestaan Sosiolinguistik. UM: Malang.

Mahali, Saidatul Nornis Hj. 2008. Strategi interaksi dalam tradisi lisan Isun-Isun Bajau. SARI: Jurnal Alam dan Tamadun Melayu. 26(15).

Malabar, Sayama. 2015. Sosiolinguistik. Ideas Publishing: Gorontalo.

Mustikawati, Diyah Atiek. 2015. Register Bahasa Transportasi (Studi Pemakaian Bahasa Kelompok Profesi). Makalah disampaikan dalam Prosiding Seminar Nasional Pendidikan, FKIP, Universitas Muhammadiyah Ponorogo, Ponorogo, 7 November 2015.

Prasetya, Tutut. 2013. Bentuk, Makna, dan Fungsi Register Tni AD di Bekangdam V Brawijaya Surabaya: Suatu Kajian Sosiolinguistik. SKRIPTORIUM. 1(3).

Rokhman, Fathur. 2013. Sosiolinguistik: Suatu Pendekatan Pembelajaran Bahasa dalam Masyarakat Multikultural. Graha Ilmu: Yogyakarta.

Sugiyono. 2018. Metode Penelitian Kuantitatif, Kualitatif, dan R\&D. Alfabeta: Bandung.

Wilga, Secsio Ratsja Putri, R. Nunung Nurwati, \& Meilanny Budiarti S. 2016. Pengaruh Media Sosial Terhadap Perilaku Remaja. PROSIDING KS: RISET \& PKM. 3(1). 